\title{
NEWS FOLLOW IN PERIODS OF CRISIS ${ }^{1}$
}

\author{
Kriz Dönemlerinde Haber Takibi \\ Research Assistant, Faruk TEMEL ${ }^{2}$ \\ Erciyes University, Communication Faculty, Journalism Department, \\ Kayseri \\ Lecturer, Osman UTKAN ${ }^{3}$ \\ Erciyes University, Communication Faculty, Public Relations Department, \\ Kayseri
}

\begin{abstract}
Crises faced in political, social and economic context have different characteristics if compared to normal times. Nowadays, "news" has an important position among the media contents in those periods, when collective information flow is reflected through the media. On the other hand, during the periods of crisis, when the need for information is expected to increase, the course of news following is crucial. In this context, the question of this study is the kind of quality the news following has in periods of crisis and whether it makes a difference in terms of quantity when compared to the normal times. The research, which aims to reveal qualitative conclusions by obtaining quantitative data on news following through a questionnaire study conducted on the academicians, has been applied to the academicians who work at Erciyes University. As a result of the research, it was determined that the mass media were followed up more than the normal times during the periods of crisis. During periods of political and social crises, when the individuals intensively experience the timeliness, closeness and importance criterion of the event, information demand and news following get more intense than the other times.
\end{abstract}

Keywords: Periods of crisis, media, news following

Özet: Siyasal, toplumsal ve ekonomik alanda yaşanan krizler normal zamanlara göre farklı özellikler taşımaktadır. Günümüzde topluma bilgi akışının medya aracılığıyla yansıtıldığı bu dönemlerde medya içeriklerinden "haber" önemli bir konuma oturmaktadır. Diğer yandan bilgi edinme ihtiyacının arttığı düşünülen kriz dönemlerinde, haber takibinin seyri önem arz etmektedir. Bu çerçevede kriz dönemlerinde haber takibinin nasıl bir nitelik taşıdığı ve nicelik bağlamında normal zamanlara göre bir farklılık oluşturup oluşturmadığı araştırmanın konusudur. Akademisyenlere yönelik gerçekleştirilen anket çalışmasıyla haber takibi konusunda niceliksel veriler elde ederek, niteliksel çıkarımlar ortaya koymayı amaçlayan araştırma Erciyes Üniversitesi'nde görevli akademisyenlere yönelik uygulanmıştır. Araştırma sonucunda kriz dönemlerinde kitle iletişim araçlarının normal zamanlara göre daha fazla takip edildiği saptanmıştır. Bireylerin, olaya ilişkin zamanlılık, yakınlık ve

\footnotetext{
${ }^{1}$ This Study "News Follow In Periods Of Crisis" which was presented in the "X. European Conference on Social and Behavioral Sciences" in Sarajevo on 19-22 May 2016.

2 faruktemel@erciyes.edu.tr

3 osmanutkan@erciyes.edu.tr
} 
önemlilik ölçütlerini yoğun biçimde yaşadığı siyasal ve toplumsal kriz dönemlerinde; bilgilenme isteği ve haber takibi diğer zamanlara göre yoğunlaşmaktadır.

\section{Anahtar Kelimeler: Kriz dönemleri, medya, haber takibi}

\section{Introduction}

While the concept of "crisis" refers to an event or a series of events that develops in an unexpected and sudden way, interrupts the flow of daily life in various forms and has the potential of shaking the existing social order, it is described to define serious cases which gain visibility by such different social, economic, politic, and moral facts as war, rebellion, terrorism, attacks, disease, economic crisis, political unrest, natural disasters, and accidents are intertwined in various ways (Lee and Bottomley, 2012:271; Çaplı and Taş, 2016). In such a period, while the state and its institutions are gaining importance as a crisis manager, the position of community faced with crisis directly or indirectly and of media conveying information is then so important. While the will of getting information at once about what's going in the times of crisis causes a powerful need of information for the effort to adapt to the new situation (Çaplı and Taş, 2016), "news", as one of the dominant contents of media, affects the course of crisis with its feature of reporting and with its function that sets a link with society on the other hand. The position of media that draws the first picture about crisis in the minds of individuals is important in this regard (SEMA, 2008: 11).

When considered that means of communication provide information, set mutual links and actuate these links and also continue these bonds by establishing functional bonds (Solmaz, 2007: 278), news which is an important product for media organizations with its commercial, political, and social characteristics carries utmost importance for individuals in desire of getting information who have a position of receiver. While news includes reporting or further targets in terms of media with its quality of linking with society in various purposes, it ensures the emergence of a follow-up mechanism that it includes getting information or further purposes in terms of audience. This mechanism is realized in accordance with the audience's need of getting information to follow the news from the media contents. News follow-up refers to the process of get information that are shaped and changed in direction of people's interests and personal agenda, media agenda, and political and social agenda.

When considered such values of news defined as transferring of idea, event, and problem, which are interested in human and become timely by formulating (Yüksel and Gürcan, 2005: 54), as timeliness, proximity, significance, results, and drawing attention (Tokgöz, 2003: 200), the periods of political and social crisis refer to the period when the criteria defining "news value" are intensively met. When thought that the content of news arouses interest at the periods of crisis and becomes important, it is predicted that there are differences between news follow-up in the periods of political and social crisis and normal times. In this context, it is sought an answer to the question how news follow-up is realized in the periods of political and social crisis and whether or not there is any difference between news follow-up between in the periods of political and social crisis and normal times. The study conducted for academics is expected to offer a clue about the social layers. On the other hand, it is desirable to measure the relationship between academics' use of media types and media tools.

\section{Definition of Research and Method}

The universe of research which aims at revealing quantitative arguments by obtaining qualitative data on news follow-up in the periods of crisis consists of academics of Erciyes University. The total number of academics, 
member of Erciyes University, is $2330^{4}$. 154 academics determined by simple random sampling method constitute the sample of research. The data obtained from the academics implemented a survey ${ }^{5}$ in which are various questions about media use and news follow-up in the periods of crisis has been analyzed by SPSS software program and solved by frequency analysis, t-test, and correlation test.

\section{Findings}

\subsection{Demographic Characteristics}

While $83.2 \%$ of 154 participants are academics in the field of social sciences, $16.8 \%$ of that consist of academics who study in the field of digital sciences. On the other hand, $63.6 \%$ of the participants are male academics and $35.7 \%$ are female academics. By the titles of academics, Research Assistants (47.1 percent) participate more than academics who have other titles. The titles of other participants are: Asst. Prof. Dr. (13.7 percent), Lecturer (11.8 percent), Assoc. Prof. Dr. (10.5 percent), Prof. Dr. (7.8 percent), Instructor (7.8 percent), and Expert (1.3 percent).

\subsection{Media Usage Frequency of Academicians}

Table 1: Distribution for the Frequencies of Usage of TV, Newspapers, Radio, and Internet Medias

\begin{tabular}{|c|c|c|c|}
\hline & Number & Mean & Std. Deviation \\
\hline TV & 151 & 3,35 & 1,40 \\
\hline Newspaper & 149 & 3,01 & 1,44 \\
\hline Radio & 148 & 2,61 & 1,39 \\
\hline Internet & 153 & 4,79 & 0,56 \\
\hline
\end{tabular}

In the table which measures the weekly media usage of academics, it appears that media follow-up in normal times varies from the type of mass media. Internet usage (4.79) is seen almost in a regular level of the day, and its weekly usage is in the highest level by the other mass media. Television (3.35) and newspapers (3.01) are followed for three or four days in a week. Radio (2.61) is listened for ones or two times in a week by academics as the least followed tool compared to other mass media.

Table 2: Distribution for the Frequencies of Usage of TV, Newspapers, Radio, and Internet Medias in Order to Follow News

\begin{tabular}{|c|c|c|c|}
\hline & Number & Mean & Std. Deviation \\
\hline TV & 152 & 3,46 & 1,45 \\
\hline Newspaper & 148 & 3,10 & 1,52 \\
\hline Radio & 147 & 1,94 & 1,12 \\
\hline Internet & 117 & 4,57 & 0,90 \\
\hline
\end{tabular}

For academics, Internet (4.57) is the most followed tool for five or six days in a week in order to follow news compared to the other mass media. Television (3.46) and newspapers (3.10) are followed for three or four days in a week. Radio (1.94) is listened for one or two days in a week as the least followed tool inside the mass media.

\footnotetext{
${ }^{4}$ The information related to the number of academics on duty at Erciyes University has been taken from the Department of Personnel of Erciyes University in April 2016.

${ }^{5}$ For preparation of the scale, it has been benefitted from the study called "Siyasal Bilgilenmede iletişim Araç ve Yöntemlerinin Önem Düzeyi: 29 Mart 2009 Yerel Seçimleri Konya Araştırması".
} 
Table 3: Distribution for the Frequencies of Usage of TV, Newspapers, Radio, and Internet Medias in Order to Follow News in the Periods of Crisis

\begin{tabular}{|c|c|c|c|}
\hline & Number & Mean & Std. Deviation \\
\hline TV & 152 & 3,98 & 1,23 \\
\hline Newspaper & 151 & 3,30 & 1,34 \\
\hline Radio & 151 & 2,26 & 1,26 \\
\hline Internet & 153 & 4,61 & 0,78 \\
\hline
\end{tabular}

Internet (4.61), in the usage of mass media in order to follow news in the periods of crisis, stands out as the most used tool compared to the other tools with its almost daily regular usage. While Television (3.98) for five or six days in a week and Newspaper (3.30) for three or four times in a week are following, Radio (2.26) is listened for one or two days in a week as the least followed tool in order to follow news in the periods of crisis. Note: When the difference between media usage in the news follow-up for normal times and crisis periods, chisquare test results show that the being more of news follow-up in the periods of crisis according to normal times is statistically significant with the value, 00

Table 4: Media Usage Differences by Gender

\begin{tabular}{|r|c|c|c|c|c|}
\hline \multirow{2}{*}{ Gender } & \multicolumn{5}{|c|}{ Radio Listening Frequency in Order to Follow News in Times of Crisis } \\
& Number & Mean & Std. Deviation & T & P \\
\cline { 2 - 6 } & Male & 97 & 2,11 & 1,10 & $-1,856$ \\
\hline Female & 53 & 2,50 & 1,47 & &, 001 \\
\hline
\end{tabular}

The table shows that the radio listening frequency of female participants in times of crisis in order to follow news $(, 027)$ is more than the radio listening frequency of male participants in normal times $(, 020)$.

Table 5: Correlation Analysis Between Media Usages According to Purpose Of Using

\begin{tabular}{|c|r|r|r|r|r|r|r|r|}
\hline & TV & $\begin{array}{r}\text { Order to Follow } \\
\text { News) }\end{array}$ & $\begin{array}{r}\text { News } \\
\text { paper }\end{array}$ & $\begin{array}{r}\text { Newspaper } \\
\text { (In Order to } \\
\text { Follow News) }\end{array}$ & $\begin{array}{r}\text { Radio } \\
\text { (In Order } \\
\text { to Follow } \\
\text { News) }\end{array}$ & $\begin{array}{r}\text { Internet } \\
\text { Internet } \\
\text { In Order to } \\
\text { Follow News) }\end{array}$ \\
\hline TV & 1 & $0,765^{* *}$ &, $302^{* *}$ &, $211^{*}$ &, 080 &, 006 &, 028 &, 051 \\
\hline $\begin{array}{c}\text { In Order to Follow } \\
\text { News) }\end{array}$ & $0,765^{* *}$ & 1 &, $367^{* *}$ &, $368^{* *}$ &, 122 &,- 003 & 0,68 &, 054 \\
\hline $\begin{array}{l}\text { Newspaper } \\
\text { Newspaper } \\
\text { (In Order to } \\
\begin{array}{l}\text { Follow } \\
\text { News) }\end{array}\end{array}$ &, $302^{* *}$ &, $367^{* *}$ & 1 & $0,915^{* *}$ &, 072 &,- 042 &,- 003 &, $242^{* *}$ \\
\hline
\end{tabular}




\begin{tabular}{|l|r|r|r|r|r|r|r|r|}
\hline \multicolumn{1}{|c|}{ Radio } &, 080 &, 122 &, 072 &, 090 & 1 & $0,616^{* *}$ &, $224^{* *}$ &, 113 \\
\hline $\begin{array}{l}\text { (In Order to Follow } \\
\text { News) }\end{array}$ &, 006 &, 122 &,- 042 &,- 004 & $0,616^{* *}$ & 1 &, 145 &, 149 \\
\hline $\begin{array}{l}\text { Internet } \\
\text { Internet } \\
\begin{array}{l}\text { In Order } \\
\text { Follow News) }\end{array}\end{array}$ & 028 &, 068 & 003 &, 146 & $224^{* *}$ &, 145 & 1 &, $625^{* *}$ \\
\hline
\end{tabular}

*: Relation, significant at the 0.01 level. **: Relation, significant at the 0.05 level.

There is a significant relationship between the usage of these medias in order to the use of TV, newspaper, radio, and Internet and news follow-up in normal times. But the intensity of relationship varies. Type of media is effective for news follow-up because the most intensive relationship belongs to newspaper. The intensity of difference is not being intensive, compared to normal times, because radio is used only for listening and news content is not intensive according to other features. Besides, particularly Internet, because TV offers different alternatives, the intensity of relations becomes low when compared to newspaper. There is a low-intensive significant relationship between those who read newspapers and those who watch TV in order to follow news in normal times. It appears a statistically significant relationship between those who read newspapers and those who watch TV in order to follow news in normal times as well. Additionally, there is a significant and intensive/powerful relationship between those who read newspapers and the usage of Internet in order to follow news in normal times. This case shows that readers of newspapers indeed read a newspaper on Internet at the same time.

Table 6: The Correlation Analysis Between Media Usages In Different Times

\begin{tabular}{|c|c|c|c|c|c|c|c|c|}
\hline & $\begin{array}{r}\text { TV } \\
\text { (In } \\
\text { Order to } \\
\text { low News) }\end{array}$ & $\begin{array}{r}\text { (Periods of } \\
\text { crisis) }\end{array}$ & $\begin{array}{l}\text { Newspaper } \\
\text { (In Order to } \\
\text { Follow News) }\end{array}$ & $\begin{array}{r}\text { Newspaper } \\
\text { (Periods of } \\
\text { crisis) }\end{array}$ & $\begin{array}{r}\text { (In Order to } \\
\text { Follow } \\
\text { News) }\end{array}$ & $\begin{array}{r}\text { Radio } \\
\text { Periods of } \\
\text { crisis) }\end{array}$ & $\begin{array}{r}\text { Internet } \\
\text { (In Order to } \\
\text { Follow } \\
\text { News) }\end{array}$ & $\begin{array}{r}\text { Internet } \\
\text { (Periods of } \\
\text { crisis) }\end{array}$ \\
\hline $\begin{array}{r}\text { TV } \\
\text { (In Order to } \\
\text { lllow News) }\end{array}$ & 1 &, $654^{* *}$ & &, $364 * *$ & & 146 & &,- 039 \\
\hline $\begin{array}{r}\text { TV } \\
\text { (Periods of } \\
\text { crisis) }\end{array}$ & ,654** & 1 & ,261** & & -,088 & & ,048 & \\
\hline $\begin{array}{r}\text { Newspaper } \\
\text { (In Order to } \\
\text { Follow } \\
\text { News) }\end{array}$ & &, $261 * *$ & 1 & ,760** & &,- 044 & & ,228** \\
\hline
\end{tabular}




\begin{tabular}{|c|c|c|c|c|c|c|c|c|}
\hline $\begin{array}{r}\text { Newspaper } \\
\text { (Periods } \\
\text { of crisis) }\end{array}$ & , 261** & &, $760^{* *}$ & 1 & -,044 & & ,228** & \\
\hline $\begin{array}{r}\text { Radio } \\
\text { (In Order to } \\
\text { Follow } \\
\text { News) }\end{array}$ & & -088 & & -,068 & 1 & ,693** & & ,216** \\
\hline $\begin{array}{r}\text { Radio } \\
\text { (Periods } \\
\text { of crisis) }\end{array}$ & ,088 & &,- 068 & & $693 * *$ & 1 & $216^{* *}$ & \\
\hline $\begin{array}{r}\text { Internet (In } \\
\text { Order to } \\
\text { Follow } \\
\text { News) }\end{array}$ & & ,048 & & ,209* & & 102 & 1 & $496^{* *}$ \\
\hline $\begin{array}{r}\text { Internet } \\
\text { (Periods of } \\
\text { crisis) }\end{array}$ & 048 & & ,209* & & ,102 & & $496 * *$ & 1 \\
\hline
\end{tabular}

There is a significant relationship between the usage of TV, newspaper, radio and Internet in order to news follow-up and the usage of the same medias in order to news follow-up in periods of crisis. There is also a significant relationship between watching TV in order to news follow-up and reading newspapers in periods of crisis. Additionally, it appears the same relationship between reading newspapers in order to news follow-up and watching TV in periods of crisis. There is a positive significant relationship between reading newspapers in order to news follow-up and the usage of Internet in periods of crisis. This case is seen also between the usage of Internet in order to news follow-up and newspaper follow-up in periods of crisis. There is a significant relationship between those who listen radio in order to news follow-up and the usage of Internet in periods of crisis. Just as it happens for newspaper, this relationship shows that newspaper and radio are followed by Internet.

\subsection{Academics and News Follow-Up}

Table 7: Averages for the Confidence Interval to Mass Media in News Follow-Up

\begin{tabular}{|c|c|c|c|}
\hline & Mean & Std. Deviation & Number \\
\hline Internet & 4,89 & 2,33 & 153 \\
\hline TV & 4,66 & 2,35 & 154 \\
\hline Newspaper & 4,60 & 2,11 & 151 \\
\hline Radio & 4,34 & 2,08 & 148 \\
\hline
\end{tabular}

In the confidence scale between 1 and 9, it appears that the confidence level to the whole mass media is under the middle degree. By there are clear differences between them; while Internet is the most confiding tool according to the participants with an average 4.89 , television is 4.66 , and newspaper is 4.60 . The least confiding, compared to the others, is seen as radio (4.34), besides. 
Table 8: Averages for the Confidence Interval to Internet Contents in News Follow-Up

\begin{tabular}{|c|l|l|l|l|}
\hline & umber & ercentage & hean & . Deviation \\
\hline Official Internet Pages of Newspapers & 154 & 100 & 5,46 & 2,07 \\
\hline News Portals & 152 & 98,7 & 4,94 & 1,89 \\
\hline Forums & 151 & 98,1 & 3,60 & 1,88 \\
\hline Sharing Networks (Twitter, Facebook etc.) & 150 & 97,4 & 3,04 & 1,76 \\
\hline
\end{tabular}

In terms of confidence to news sources, it appears that academics have more confidence to Official Internet Pages of Newspapers and News Portals than Forums and Social Sharing Networks among the Internet contents. While social sharing networks are the least confiding news sources in the confidence scale between 1 and 9 , the confidence to official internet pages of newspapers on web is above average.

Table 9: Frequency of Commenting on Social Networks (Twitter, Facebook, YouTube etc.)

\begin{tabular}{|c|c|c|c|c|c|}
\hline \multirow{7}{*}{$\begin{array}{l}\frac{n}{n} \\
\frac{n}{2} \\
40 \\
\frac{n}{0} \\
\frac{0}{2} \\
\frac{0}{0} \\
0 \\
\underline{c}\end{array}$} & Options & lumber & Percentage & hean & Std. Deviation \\
\hline & Never & 85 & 55,2 & \multirow{5}{*}{1,74} & \multirow{5}{*}{1,03} \\
\hline & 1-2 days per week & 38 & 24,7 & & \\
\hline & 3-4 days a week & 22 & 14,3 & & \\
\hline & 5-6 days per week & 3 & 1,9 & & \\
\hline & Everyday regularly & 6 & 3,9 & & \\
\hline & TOTAL & 154 & 100,0 & & \\
\hline \multirow{6}{*}{ 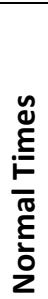 } & Never & 67 & 43,5 & \multirow{5}{*}{$-2,00$} & \multirow{5}{*}{1,54} \\
\hline & 1-2 days per week & 46 & 29,9 & & \\
\hline & 3-4 days a week & 24 & 15,6 & & \\
\hline & 5-6 days per week & 8 & 5,2 & & \\
\hline & Everyday regularly & 9 & 5,8 & & \\
\hline & TOTAL & 154 & 100,0 & & \\
\hline
\end{tabular}

While frequency of commenting on social networks is in the level of 1-2 days per week, this rate partially decreases in periods of crisis. This case shows that academics behave timidly for social sharing networks particularly in times of crisis

Table 10: Percentage Distribution to What Extent the Participants Follow Which of the News Contents

\begin{tabular}{|c|l|l|l|c|}
\hline NEWS CONTENTS & Number & Percentage & Mean & Std. Deviation \\
\hline Latest News & 153 & 99,4 & 4,13 &, 86 \\
\hline Political News & 154 & 100 & 3,87 & 0,99 \\
\hline World News & 152 & 98,7 & 3,49 & 1,12 \\
\hline Culture \& Arts News & 153 & 99,4 & 3,48 & 1,00 \\
\hline Economic News & 150 & 97,4 & 3,14 & 1,11 \\
\hline Health News & 152 & 98,7 & 3,07 & 1,11 \\
\hline Religious News & 152 & 98,7 & 2,96 & 1,08 \\
\hline Public Security News & 150 & 97,4 & 2,76 & 1,02 \\
\hline Sports News & 152 & 98,7 & 2,50 & 1,31 \\
\hline Magazine News & 149 & 96,8 & 1,94 &, 88 \\
\hline
\end{tabular}


It is seen that academics more follow latest news $(4,13)$, and respectively, political news $(3,87)$, world news $(3,49)$ and culture $\&$ art news $(3,48)$. Magazine news $(1,94)$ are the least followed news by the participants compared to the other types of news.

Table 11: Differences by Gender in News Follow-Up

\begin{tabular}{|c|c|c|c|c|c|c|c|c|c|c|}
\hline & & Sports & News & & & & Culture & \& Art New & & \\
\hline & Number & Mean & $\begin{array}{r}\text { Std. } \\
\text { viation }\end{array}$ & $\mathbf{T}$ & $\mathbf{P}$ & Number & Mean & Peviation & $T$ & $\mathbf{P}$ \\
\hline Male & 98 & 89 & 31 & & & 98 & $\beta, 38$ & 1,09 & & \\
\hline Female & 53 & 81 & 00 & & PUL & 54 & 3,62 & 807 & & \\
\hline
\end{tabular}

Male participants follow sport news more than female participants. On the other hand, female academics follow culture \& arts news follow more than male academics. There is a statistically significant difference between female and male academics.

Table 12: Importance of Various Factors in News Follow-Up

\begin{tabular}{|c|c|c|c|}
\hline & Number & Mean & Std. Deviation \\
\hline Personal Interests & 153 & 4,34 &, 837 \\
\hline Career Interests & 152 & 4,35 &, 784 \\
\hline Political and Social Crises & 152 & 4,27 &, 839 \\
\hline Media Agenda & 153 & 4,27 &, 828 \\
\hline
\end{tabular}

Among the determining criteria in news follow-up, the factors related to individual himself such as Career Interests $(4,35)$ and Personal Interests $(4,34)$ are seen as partially higher compared to the foreign determining factors such as times of Political and Social Crises $(4,27)$ and Media Agenda $(4,27)$. However, there is not a clear difference in appearance. It appears that the four determining reasons are accepted as important by participants for news follow-up.

Table 13: Correlation Analysis Between Types of News and Some Factors in News Follow-Up

\begin{tabular}{|c|c|l|l|l|}
\hline & sonal Interests & reer Interests & $\begin{array}{l}\text { litical and Social } \\
\text { Crises }\end{array}$ & Media Agenda \\
\hline World News &, 104 &, 081 &, $295^{* *}$ &, $257^{* *}$ \\
\hline Political News &, $191^{*}$ &, 063 &, $441^{* *}$ &, $277^{* *}$ \\
\hline Financial News &, 081 &, 145 &, $297^{* *}$ &, $285^{* *}$ \\
\hline Magazine News &,- 077 &,- 022 &, 097 &, 086 \\
\hline Sports News &, 026 &, 023 &, 032 &, $298^{* *}$ \\
\hline Public Security News &,- 023 &,- 018 &, $215^{* *}$ &, $365^{* *}$ \\
\hline Latest News &, 107 &, $218^{* *}$ &, $173^{*}$ &, 010 \\
\hline Culture \& Arts News &, 120 &, $183^{*}$ &, 149 &, $252^{* *}$ \\
\hline Health News &, 009 &, $180^{*}$ &,- 025 &, 071 \\
\hline
\end{tabular}

There is a significant and positive relationship in appearance between world news, political news, financial news, public security news, latest news and periods of crisis. When thought that political and social 
crises generally include political, economic, and social matters, it can be said that those who are interested in the types of political, financial, and world news make more intensive follows-up in times of political and social crises.

Table 14: Frequency of News Follow-Up in Periods of Political and Social Crisis

\begin{tabular}{|c|l|l|l|c|}
\hline & Number & Percentage & Mean & $\begin{array}{c}\text { Std. } \\
\text { Deviation }\end{array}$ \\
\hline Terrorist Attacks and Martyrs News & 153 & 99,4 & 4,26 & 0,95 \\
\hline June 7th Elections & 151 & 98,1 & 4,09 & 0,99 \\
\hline December 17 to 25 Operations & 148 & 96,1 & 4,07 & 1,10 \\
\hline Gezi Events & 151 & 98,1 & 3,98 & 1,16 \\
\hline Dropped the Russian plane by Turkey & 152 & 98,7 & 3,97 & 1,05 \\
\hline Refugee Crisis & 151 & 98,1 & 3,58 & 1,06 \\
\hline
\end{tabular}

It is seen that participants follow for five or six days in a week in times of crisis. It appears that type and intensity of the crisis are related to frequency of news follow-up. While refugee crisis is seen as the least followed process compared to the others, it seems to be more effective in this case that it spreads over time and the source of the problem is another country. All of the other crises reflect the crises that Turkey is directly faced and more on its domestic issues.

Table 15: The Participation Rate to Statements Related to News Follow-Up in Times of Crisis

\begin{tabular}{|c|c|c|c|c|}
\hline & Number & Percentage & Mean & d. Deviation \\
\hline $\begin{array}{r}\text { pw more than one source to ensure the accuracy of the news in the periods } \\
\text { of political and social crisis. }\end{array}$ & 152 & 98,7 & 4,40 & 85 \\
\hline $\begin{array}{r}\text { My intensity of news follow-up is increasing in times of political and social } \\
\text { crisis. }\end{array}$ & 154 & 100 & 4,27 & 0,92 \\
\hline I follow multiple mass media in periods of political and social crisis. & 153 & 99,4 & 4,23 & 0,86 \\
\hline $\begin{array}{l}\text { My Internet usage increases in periods of political and social } \\
\text { crisis compared to other times. }\end{array}$ & 153 & 99,4 & 4,04 & 1,02 \\
\hline $\begin{array}{l}\text { I follow only channels appropriate to my political ideology } \\
\text { in periods of political and social crisis. }\end{array}$ & 153 & 99,4 & 2,28 & 1,09 \\
\hline p not certainly watch and follow news in periods of political and social crisis. & 153 & 99,4 & 1,59 & 0,96 \\
\hline
\end{tabular}

The statements used 5-Point Likert Scale have been measured as "strongly disagree, disagree, undecided, agree and strongly agree". The participants' expression of "I follow more than one source to ensure the accuracy of the news in the periods of political and social crisis" is the level of "strongly agree". Also the expressions of "My intensity of news follow-up is increasing in times of political and social crisis", "I follow multiple mass media in periods of political and social crisis", and "My Internet usage increases in periods of political and social crisis compared to other times" are in the level of "agree". Finally, the statements of "I follow only channels appropriate to my political ideology in periods of political and social crisis" and "I do not certainly watch and follow news in periods of political and social crisis" are in the level of "disagree".

\section{Conclusion}

It appears that mass media is followed more in times of crisis. Individuals intensively experience the criteria of timeliness, proximity, and importance related to the event. The will of getting information and news follow-up 
in times of political and social crisis become intensive compared to other times. It supports the conclusion that news follow-up increases in times of crisis because those who intensively follow world news, political news, financial news, public security news, and latest news increase their intensity in news follow-up in periods of crisis.

The data obtained from the research shows that academics do not ideologically behave in news followup, they feel the need of following news via multiple sources and try to reach accurate information. On the other hand, types of media direct audience in relation to other types of media in periods of crisis. Particularly in media follow-up for following news in times of crisis, there is a statistical relationship between Internet and newspaper, newspaper and television, and Internet and radio. This case shows both the media follow-up of audience is the conclusion of influence of extraordinary period and there is a link between medias.

Despite the extensive usage of Internet in media use by academics, there is a cautious use in social media. It is seen that they do not comment very frequently while executing a usage in order to follow content, and in this respect, the active usage has a weak rate. When mass effect of social media is considered, despite a more intensive use in times of crisis (Önürmen, 2015: 275), academics use Internet intensively, but frequency of commenting on social media more decreases in periods of crisis. On the other hand, academics almost do not trust the contents in social media and forums among Internet content. Therefore, it is possible to say that academics do not see particularly social media and forums as a source of knowledge. Official webpages are found more reliable in this regard by academics.

While an intensive follow-up takes place in the periods of political and social crisis experienced in Turkey, refugee crisis is found to be the least followed period of crisis among them. Types, contents, feeling of intimacy, and case of time of the crises are effective in the intensity of news follow-up. On the other hand, it is possible to be among the reasons which show that academics abstain from Internet because the crises experienced in Turkey carry political contents.

According to the results of the study which has been carried out towards academics who have a different position in society with their various characteristics; it can be made a prediction on media usage and news follow-up are related to social layers and status. So much so that, it can be thought that various results of the research are linked with the professional characteristics of the academics. The studies to be made on other layers of society who carry other demographic characteristics will allow to be obtained clear information.

\section{References}

Balcı Ş. \& Akar H. (2010). Siyasal Bilgilenmede Illetişim Araç ve Yöntemlerinin Önem Düzeyi: 29 Mart 2009 Yerel Seçimleri Konya Araştırması [ Sıgnıfıcance Level Of Communıcatıon Vehıcles And Methods On Beıng Political Informed: Konya Research Of 29 March 2009 Local Elections], E-Journal of New World Sciences Academy, (5) 2, 282-305.

Çapıı B. \& Taş O., Kriz Haberciliği [Crisis Reporting], http://ilefarsiv.com/etik/kriz-haberciligi (Access Date: 10 May 2016)

Lee, T. \& Bottomley, J., (2010). Commentary: Pending crises: Crisis Journalism and SARS in Australia, Asia Pacific Media Educator, 20, 269-276.

Önürmen O., (2015). Cumhurbaşkanlığı Seçim Sürecinde Kamusal Alanın Sosyal Medya Yoluyla Oluşması: Twitter Örneği [Social Media Formation Of Public Sphere In The Presidential Election Process: e.g. Twitter], Cumhurbaşkanlığı Seçimi ve Medya [Presidential Election and Media], (Ed. Temel F. \& Önürmen O.), Nobel Yayınları, Ankara 
Solmaz B., (2007). Basının Sosyal Sorumluluğu [The Social Responsibility Of The Press], Bir Sorun Olarak Gazetecilik [Journalism As a Problem], (Edt. Arık B. \& Şeker M.) Tablet Yayınları, Konya

Swedish Emergency Management Agency (SEMA), (2008). Crisis Communications Handbook, Jupiter Reklam AB, NRS Tryckeri, Huskvarna,

Tokgöz, O., (2003). Temel Gazetecilik [Basic Journalism] , İmge Kitabevi, Ankara

Yüksel E. \& Gürcan H. İ., (2005) Haber Toplama ve Yazma [News Gathering and Writing], Tablet Yayınları, Konya 